ACQUISITIONS

- Fresno State College library has purchased the Roy Brady collection of books and related materials on wine, grapes, and winemaking. The collection consists of about fifteen hundred books, fourteen hundred pamphlets, nine hundred wine merchants' catalogues, two hundred wine lists, seventeen hundred and fifty issues of periodicals, and miscellaneous ephemera. The collection was formed over a period of twenty years by Mr. Brady.

- Recent accessions of the manuscript division of the LiBraRY of Congress have included the papers of John Glenn, astronaut, numbering about ninety thousand items. While they consist chiefly of fan letters sent to Glenn between 1962 and 1964, plus some copies of Glenn's replies, there are also subject files, space manuals, newspaper clippings, scrapbooks, certificates and awards, and maps and charts.

The literary collections have been augmented by the papers of novelist John Barth. These include notes, manuscripts, typescripts, galley proofs, and page proofs of Giles GoatBoy, The Sot-Weed Factor, The Floating Opera, and The End of the Road.

Recent additions to the papers of Daniel Webster include letters and autograph notes to a speech to the Senate, March 7, 1850, in favor of Clay's compromise measures. Attached to the notes is an autograph letter of Joseph $\mathbf{H}$. Choate, Ambassador to Great Britain, December 3,1900 , in which Choate, referring to the notes, says that probably Webster expected his speech would startle his friends in New England "and he wanted to be sure of every word."

Two of the Presidential collections have received additions, the papers of Franklin Pierce and the papers of John Tyler.

- A large number of the papers of former Vice President Henry A. Wallace have been placed with the UnIversity of Iowa libraries by his widow, Mrs. Ilo B. Wallace, of South Salem, New York, and his children: Robert B. Wallace, of Doylestown, Pennsylvania, Henry B. Wallace, of Des Moines, Iowa, and Jean Wallace Douglas, of Washington, D.C.

- Two additions to the Bowdorn College library's special collections of individual authors have been made by Elizabeth Coatsworth Beston, wife of the late naturalist and author Henry Beston, and Marguerite Yourcenar, the noted French author. Mrs. Beston presented a collection of her husband's works and books containing selections and references to him and to his work. Mr. Beston is perhaps best remembered for his book, "The Outermost House." Miss Yourcenar's reconstruction of the life and times of the Emperor Hadrian in her book, "Memoirs of Hadrian," has been translated from the original French into Croatian, Dutch, Italian, Japanese, Norwegian, Polish, Portuguese, Swedish and English. These books and copies of her many novels, essays, plays, poems and translations are included in her gift to the Bowdoin library.

- At a small reception in the rare book room of the Linda Hall library, Joseph C. Shipman, director of the library, received the first fortytwo volumes of the eighty-two-volume facsimile reprint edition of the "Annual Reports and General Appendices of the Smithsonian Institution, 1846-1932." The set was donated by the publisher, William Buchanan of Carrollton Press, in Washington, D.C.

- The papers of Andrew Nelson Lytle, distinguished Southern author and educator, have been acquired by the Joint University Libraries, Nashville. The collection contains approximately thirty five hundred items for the period 1868-1966 and includes both incoming and outgoing correspondence, manuscripts, accounts, biographical and genealogical material, contracts, clippings, diaries, land and estate records, invitations, passports, programs, and wills.

- The Lois Goodard Morrison collection of eighteenth century English literature has been acquired by the San Antonio College library. The Morrison collection consists largely of books published before 1800 , along with later bibliographical and supportive monographs with special emphasis on the works of Eustace Budgell, publications by A. Moore, and with representation of more than two hundred different authors.

- Sam Houston State College has purchased the entire criminology library of Sanford Bates of Pennington, N.J. Dr. Bates was head of the Federal Bureau of Prisons from 1930 to 1937 and served as the U.S. Commissioner on the International Prison Commission. He is the author of many articles and the book, Prisons and Beyond. The collection of 2,000 volumes will be used to support the noted Institute of Contemporary Corrections and Behavioral Sciences at the college.

- Dr. Milburn Lincoln Wilson of Washington, D.C., Assistant Secretary of Agriculture in the Franklin D. Roosevelt administration, has presented to Montana State UnIVERstTy library his extensive collection of books and pamphlets relating to economics and to agricul- 
tural history. The university library already possesses Dr. Wilson's correspondence from the years when he was a member of the faculty. This forms a very rich lode for research and has already been used by a number of scholars who are interested in Dr. Wilson's life or in agricultural policy and experimentation of the 1930's.

\section{AWARDS, GIFTS}

- A SCIENCE INFORMATION NETWORK of libraries throughout the Gulf Coast area, to disseminate technical and scientific information to business, commerce, industry, and academic institutions is known as the Regional Communications and Information Exchange, and is located at the library of Rice University. Rice is developing centralized bibliographic references, and an intranetwork location and transfer service. The service is available to the eighteen academic institutions participating in the network, and-on an individual fee basisto outside investigators. The National Science Foundation has granted $\$ 119,250$ for the work of the Center; industry has invested approximately $\$ 40,000$, and the Office of State Technical Services of the U.S. Department of Commerce has given a total of $\$ 53,325$ in support.

Head of the project is Richard L. O'Keeffe, director of the Regional Communication and Information Exchange. The Exchange will use teletype facilities to link the college and university libraries participating in the system. In addition, Rice University will study and plan for an expanded computer-based regional bibliographic reference service, through a coordinated program of regional library acquisition and exchange.

- Montana State University library has been granted $\$ 2,000$ by the Louis $W$. and Maud Hill Family Foundation as a renewal to complete the microfilming of the Yellowstone National Park archives. These cover the period of the Army's administration of the park and contain a wealth of material in all areas relating to the park. They should be of interest to many scholars.

- The UnIversity of Washington health sciences library has been designated the $\mathrm{Pa}$ cific Northwest Regional Health Sciences library, and was awarded a grant of $\$ 142,532$ to expand its services. As a regional health sciences library it will serve physicians, dentists, nurses and other health professionals in the states of Alaska, Washington, Oregon, Idaho and Montana. Part of the grant will be used to establish a request center for MEDLARS. The regional library will prepare requests for a computer-directed search of principal medical publications for references on a particular topic. The computer processing takes place at the National Library of Medicine.

\section{B U I L D I N G S}

- Construction is complete on the new library building for ClinCH VALLeY College at Wise, Va., which cost $\$ 594,000$. The library has a total of 20,722 square feet, with a book capacity of 75,000 volumes, and reader space for 331 persons. The undergraduate facility was funded with state and federal funds. New equipment for the building will cost approximately $\$ 100,000$. Dedication of the library will take place during the coming academic year. The library was named for John Cook Wyllie, the late librarian of the Alderman library at the University of Virginia at Charlottesville.

- The projected East-West Center library building of the University of HawaII to house Asian reference material, will be constructed next to the newly-completed graduate research library on the Manoa campus.

\section{FELLOWSHIPS, SCHOLARSHIPS}

- The library school of the UNIVErsity of Minnesota invites application for $\$ 2,400$, tuition-free fellowships available under a grant from the Public Health Service. The purpose of the program is to prepare information specialists conversant with and capable of handling the expanding activities of biomedical information centers, especially in the use and development of new information storage and retrieval techniques. Successful applicants may begin their study in September or in January 1969. To be eligible for these fellowships, students should hold a bachelor's degree, preferably in the biological sciences. The stipend of $\$ 200$ per month for twelve months of fulltime study leading to an MA degree is supplemented by free tuition. Men and women interested in a career in biomedical librarianship are invited to write to Wesley Simonton, Professor and Director of the Biomedical Librarians Program, Library School, University of Minnesota, Minneapolis, Minnesota 55455.

- The Old Dominion Foundation of New York has made a grant of $\$ 55,000$ to the Bodleian library at Oxford, the University library at Cambridge and the British Museum, so that they may carry out together some experiments in the collection of cataloging information and its handling by computer. These experiments are to be a pilot project for a union catalog of early books (up to 1801) in all languages in the British Museum and in the college and university libraries at Oxford and Cambridge. The experiments, called collectively Project LOC, are expected to take a year. The project will be administered and controlled by representatives of the three institutions and will be under the direction of J. W. Jolliffe of the British Museum. The proc- 
essing of the information will be carried out on the Titan computer at Cambridge.

\section{MEETINGS}

SEPT. 22-26: 42nd Annual Conference of Aslib, Canterbury.

Sept. 22-Oct. 4: Institute on Planning, Programming, and Budgeting Systems for Libraries, Wayne State University College of Education, Department of Library Science, and School of Business Administration, at McGregor Memorial Conference Center, conducted under a grant from USOE, Title II-B.

Sept. 24-Dec. 10: The department of library science at Rosary College, River Forest, will conduct an HEA Institute in systems analysis, as applied to libraries. This part-time institute for special librarians in the Chicago area is being conducted under a grant from the United States Office of Education through the Higher Education Act of 1965 and participants may request three semester hours of graduate credit. Criteria for eligibility include the BALS or MALS, experience in a library, and the same standards required of all who enter the department of library science at Rosary College. The exception, however, would be the applicant who does not have a BALS or MALS, but where professional experience and qualifications would be considered for enrollment. Purpose of the threehour sessions, which will meet on twelve consecutive Tuesday evenings, is to orientate librarians and administrators of special libraries to improve service, increase effectiveness, and coordinate all operations in their libraries through systems analysis. Application forms can be obtained by writing to: Sr. Marie Norbert Webner, HEA Institute in System Analysis, Rosary College, 7900 W. Division Street, River Forest, Illinois 60305 .

Ocr. 4-5: Indiana Chapter of the Special Libraries Association and the Purdue University libraries two-day meeting at Purdue University on "Automation in the Library." Mrs. Theodora Andrews, pharmacy librarian at Purdue University, is chairman in charge of meeting plans.

Ocr. 7-10: 20th annual conference of the Deutsche Gesellschaft für Dokumentation, Bad Dürkheim.

Ocr. 17-18: Institute in Chicago jointly sponsored by the Library of Congress Information Systems Office, the Division of Library Automation of ALA, and University of Chicago libraries, to explain the organization and use of LC's MARC magnetic tapes which will be available for distribution beginning Oct. 1 . The program is directed at catalogers, acquisitions librarians, heads of these departments, data processing librarians and heads of technical processes. Registration is limited to 100 . Send name and address to: ISAD/LC MARC Institutes, American Library Association, 50 E. Huron St., Chicago, Ill. 60611.

OCT. 20-24: American Society for Information Science, formerly American Documentation Institute, 31st annual meeting in Columbus, Ohio. Papers are invited on all facets of methods and mechanisms to improve the operations of information systems. The technical sessions chairman, David M. Leston, Jr., Battelle Memorial Institute, should be notified of intent to submit papers, by March 1.

Nov, 1968: The Washington University school of medicine is planning to present its fifth Symposium on Machine Methods in Libraries in November, 1968, if enough people are interested. It will be a 3-day meeting and registration will be $\$ 35$. Speakers will discuss automation at the libraries of the UN, The Royal Society of Medicine, The Upstate Medical Center's Biomedical Network, The New York Medical Center, The University of Louisville medical school, and other institutions, as well as the work of the Washington University school of medicine library. Those who might be interested in attending the Symposium should communicate with Dr. Estelle Brodman, Librarian and Professor of Medical History, School of Medicine Library, Washington University, St. Louis, Missouri 63110.

Nov.: Institute in Boston jointly sponsored by the Library of Congress Information Systems Office, the Division of Library Automation of ALA, and Harvard University library to explain the organization and use of LC's MARC magnetic tapes which will be available for distribution beginning Oct. 1. The program is directed at catalogers, acquisitions librarians, heads of these departments, data processing librarians and heads of technical processes. Registration is limited to 100 . Send name and address to: ISAD/LC MARC Institutes, American Library Association, $50 \mathrm{E}$. Huron St., Chicago, Ill. 60611.

Nov. 25-29: 19th meeting of FID/C3, Social Sciences, at Utrecht, Netherlands.

DEC. 2-7: (AIBDA) 2d Inter-American Meeting of Agricultural Librarians and Documentalists in Bogotá, Colombia.

DeC. 12-13: Institute in Atlanta, Ga., jointly sponsored by the Library of Congress Information Systems Office, the Division of Library Automation of ALA, and Georgia Institute of 
Technology library to explain the organization and use of LC's MARC magnetic tapes which will be available for distribution beginning Oct. 1. The program is directed at catalogers, acquisitions librarians, heads of these departments, data processing librarians and heads of technical processes. Registration is limited to 100. Send name and address to: ISAD/LC MARC Institutes, American Library Association, 50 E. Huron St., Chicago, Ill. 60611.

JAN. 8-10: International Conference of administrators of colleges, universities, junior colleges, and independent schools at the Americana Hotel in New York City. The theme of this conference is "Challenging a New Future" and its goal is to promote an interchange of ideas and experiences among the leaders of the higher and independent educational systems of the United States, Canada, and other nations of the world.

JAN. 27-June 5: Institute in information science, University of Southern California. Participants will be admitted on a highly selective basis. Each person will be paid $\$ 75$ per week, with $\$ 15$ per week for each dependent. Persons who are admissable and who wish credit may earn from nine to twelve units of course credit during the semester. Further information about this institute may be obtained by writing to: The Dean, School of Library Science, University of Southern California, Los Angeles, California 90007, Telephone: (213) 746-2548.

February: Institute in Cleveland jointly sponsored by the Library of Congress Information Systems Office, the Division of Library Automation of ALA, and Case Western Reserve University school of library science to explain the organization and use of LC's MARC magnetic tapes which will be available for distribution beginning Oct. 1. The program is directed at catalogers, acquisitions librarians, heads of these departments, data processing librarians and heads of technical processes. Registration is limited to 100 . Send name and address to: ISAD/LC MARC Institutes, American Library Association, 50 E. Huron St., Chicago, Ill. 60611.

MAR. 24-25: Institute in Los Angeles jointly sponsored by the Library of Congress Information Systems Office, the Division of Library Automation of ALA, and UCLA libraries to explain the organization and use of LC's MARC magnetic tapes which will be available for distribution beginning Oct. 1. The program is directed at catalogers, acquisitions librarians, heads of these departments, data processing librarians and heads of technical processes. Registration is limited to 100 . Send name and address to: ISAD/LC MARC Institutes, American Library Association, 50 E. Huron St., Chicago, III. 60611.

APRIL 14-15: Institute in Houston jointly sponsored by the Library of Congress Information Systems Office, the Division of Library Automation of ALA, and the Rice University libraries, to explain the organization and use of LC's MARC magnetic tapes which will be available for distribution beginning Oct. 1 . The program is directed at catalogers, acquisitions librarians, heads of these departments, data processing librarians and heads of technical processes. Registration is limited to 100 . Send name and address to: ISAD/LC MARC Institutes, American Library Association, $50 \mathrm{E}$. Huron St., Chicago, Ill. 60611.

MaY 5-9: A general call has been issued for "free communications," or unsolicited papers, for the Third International Congress of Medical Librarianship 1969, in Amsterdam. Papers should be 2,000 to 2,500 words long and may be submitted in one of the five Congress languages-English, French, German, Russian, and Spanish. Each paper should be accompanied by an abstract of not more than fifty words in English. October 15, 1968 is the final date for submission of papers. They should be addressed to the Office of the Secretary-General, Third International Congress of Medical Librarianship, c/o Excerpta Medica Foundation, 119 Herengracht, Amsterdam, The Netherlands. The theme of the Congress is "World Progress in Medical Librarianship." The subject areas include the contribution of medical libraries toward an increase of biomedical knowledge; the functions of medical libraries in the transmission of biomedical knowledge; the functions of the organization of medical knowledge: indexing and classification; modern information systems in medicine; technical developments in the medical library field; and problems of medical information systems and centers in developing countries. There will be invited lecturer's as well as contributed papers. Registration fee is $\$ 50$ if paid before January I; $\$ 60$ thereafter. Registration forms are available from the office of the Secretary-General. Information about special transportation to Amsterdam from the United States will be available from Mrs. Jacqueline W. Felter, The Medical Library Center of New York, 17 East 102 Street, New York 10029, and for Canada from Miss Doreen Fraser, Dalhousie University Medical Dental Library, Carleton and College Streets, Halifax, Nova Scotia.

\section{MISCELLANY}

- The fifth Medical Library Internship Program 1968/69 under the sponsorship of the 
National Institutes of Health library, which was announced earlier, has been cancelled due to recent Government employment restrictions. It is hoped that the program may be resumed for $1969 / 70$.

- CCM Information Sciences has concluded an agreement to publish the translations and other materials produced by Research \& Microfilm Publications, Washington, D.C. In addition to an annual average of more than two hundred thousand pages of research translations and related bibliographic compilations, Research \& Microfilm produces indexes and catalogs. Under terms of the agreement, CCM Information Sciences, a subsidiary of Crowell, Collier and Macmillan, will also provide managerial, sales, and product development services for the privately held micropublishing and indexing firm. Research \& Microfilm Publications provides microfilm, microfiche and printed bibliographies and indexes of all translations published by the United States Joint Publications Research Service, an intergovernmental agency that is the largest single producer of research translations in English. All subject fields are included, from more than fifty foreign languages, with emphasis on the social sciences, science and technology. Backfiles dating from 1957 are available, as are scientific and technical book translations published originally in Russian and Chinese.

- In honor of her service to the Chicago and the Illinois medical profession in general, and to the Crerar LIBrARy in particular, the Crerar library Board of Directors has established the Ella M. Salmonsen Endowment Fund, the income from which will be devoted to medical collections and services. Contributions from seventy-four of Miss Salmonsen's friends and admirers have brought the fund to a present total of $\$ 12,095$.

- The Governing Boards of Bellarmine College and Ursuline College announce the merger of the two institutions to form Bellarmine-Ursuline College, in Louisville, Kentucky.

- Charles P. Yerkes and David R. Wolf have announced the formation of a professional consulting organization in the field of MICROREPRODUCTION and microfilm information systems. Services will include information systems planning and development, product planning, market planning, market research, training, education and systems evaluation. The company, Yerkes-Wolf Associates, will be based in the Washington, D.C. area, with offices at 140 Main St. in Annapolis, Maryland.

- An 1855 first edition of Walt Whitman's "Leaves of Grass," part of the type for which the poet set himself, was presented to the Iibraries of the Massachusetts Institute of Technology as a symbol of the MIT library system's having passed the one-million volume mark. The book was the gift of I. Austin Kelly, III, a member of the MIT Class of 1926.

- Information Dynamics Comporation (IDC) of Reading, Massachusetts, has been awarded a $\$ 75,000$ contract by the Office of Education, Department of Health, Education and Welfare, Washington, D.C., to conduct a study which will provide the library and information services community with an in-depth analysis and history of the experience of the federal government in automating library and information services. The detailed analysis and history of federal automation projects, both successful and unsuccessful, will benefit the entire library and information service community by providing a comparative data base for further implementing automated services. The Federal Library Committee, through its task force on automation, is serving as an advisory committee for the project.

- An end-of-campaign statement for the $1967 / 68$ annual fund drive for the privatelysupported Research Libraries of the New YoRK PURLIC LIBRARY has just been issued by Edward G. Freehafer, director of the library. Mr. Freehafer reported that $\$ 804,100$ has been raised by the business and industry leaders who solicited gifts within their fields, and from foundations and about twenty-five hundred individuals. The campaign is the nineteenth annual appeal since that of $1949 / 50$. The branch libraries of NYPL are supported primarily by city and state funds, but the research libraries, with a current annual budget of almost $\$ 7,500,000$, derive 80 per cent of their income from private sources consisting of income from endowment and from the gifts which are raised each year in the fund drives.

- In an attempt to improve service to scholars in Ohio and to reduce some interlibrary loan costs, the Ohio State University libraries has announced that faculty members of institutions which are members of the Ohio College Library Center may borrow materials from the Ohio State University libraries directly, subject to the following provisions: (1) student circulation policies and loan periods will be followed; (2) all borrowed materials subject to recall; (3) limitations may be placed on some materials which are on demand at the Ohio State University; (4) renewals should not be expected; (5) journals will not be loaned; (6) borrowers are expected to produce proper identification (faculty ID card or a letter from home campus librarian, etc.). It is hoped that home campus li- 
braries will make arrangements with their faculties to return materials and will cooperate with and assist the Ohio State University libraries in the retrieval of overdue material. The Ohio College Library Center member libraries will send copies of their faculty directories to the circulation department, the Ohio State University libraries for the identification of faculty members. The Ohio State University libraries take this step to open library collections to all scholars in Ohio in the hope that other libraries in the state will do likewise and will continue to press for more accessibility to all library collections by scholars. If this service is successful, the Ohio State University libraries will consider further liberalizing and extending its policy.

- A John Cook Wyllie Memorial Publication Fund is being established by the BracioGRAPHICAL SOCIETY of the University of Virginia, where Mr. Wyllie had been associated with the Alderman library for forty years. The revolving fund will be used for bibliographical publications. Contributions should be made payable to "The Wyllie Memorial Fund of the Bibliographical Society of the University of Virginia" and mailed to the Society president, Mr. Linton Massey, Charlottesville, Virginia.

\section{PUBLICATIONS}

- A.L.A. Rules for Filing Catalog Cards, $2 d$ edition Abridged (Chicago: American Library Association Publishing Department, 1968. LC \#68-21020. 104p. Paper. \$2) marks completion of one phase of a five-year project. It is the first revision of ALA's filing rules. The comprehensive, unabridged Filing Rules is scheduled for late August release.

These new, official Filing Rules were prepared by a special subcommittee of ALA's Editorial Committee. The comprehensive version constitutes a very full and detailed code. The abridgement presents the same basic rules, but omits most of the specialized and explanatory material. It is expected to meet the needs of most small and medium-sized libraries for a simpler code and to serve as a basic tool for teaching filing, both on the job and in library schools. Pauline A. Seely, chairman of the committee to revise the rules, served as editor of both the comprehensive and abridged versions of the rules.

- ALA has just published the First Supplement to Winchell's Guide to Reference Books 8 th edition. The new supplement updates this internationally famous aid to the selection, use, and study of reference books. Similar in arrangement and scope to the main volume, it gives annotated descriptions of more than one thousand reference works published in all fields during the 1965-66 period. Entirely new works, new editions of works listed in the basic volume, and new parts of continuations are listed. Succinct annotations indicate content. Prices are included for most items. New features in this Supplement are Library of Congress card numbers and references to reviews in selected ALA periodicals. There are cross references to the main volume and an author, subject, title index. Eugene P. Sheehy was the compiler.

- Printing of the long-awaited National Union Catalog, Pre-1956 Imprints commenced recently in ceremonies at Wisbech, a small industrial village on the eastern coast of England. This massive retrospective bibliography, begun at the turn of the century at the Library of Congress and containing contributions from the major research libraries in the United States and Canada, is the key to all knowledge and information from the beginning of printing through 1955 on record in North America. In the glaring lights of $\mathrm{BBC}$ television cameras, Ruth Eisenhart, NUC editor for the ALA, pulled the lever that started the first pages rolling through the presses. The Mayor and Mayoress of Wisbech, bedecked in gold chains of office; representatives of the American Library Association; members of Balding \& Mansell Ltd, the printers, and Bemrose \& Sons Ltd, the binders; and officials of Mansell Information/Publishing Ltd, the publishers, witnessed the ceremonies. Now begun, the presses will not stop rolling until some ten years hence when the 704th page of the estimated 610th volume of The National Union Catalog, Pre1956 Imprints has been printed. The Mansell offices are at 3 Bloomsbury Place, London W C 1 and at 360 North Michigan Avenue, Chicago 60601.

- A survey, titled North American Library Education Directory and Statistics 1966-68, and cosponsored by the ALA Library Administration Division and the University of WisconsinMilwaukee school of library and information science, has just been published by ALA. The survey is based on statistics gathered from institutions and agencies of education for librarianship in the United States and Canada.

- Acquisitions librarians and others in the library field can now receive without charge The O-P Bookfinder, a monthly book list of out-of-print and scarce titles recently added to the microfilm collection of University Microfilms.

- ALA has just published revised editions of Personnel Organization and Procedure, for public libraries, and for college and university libraries. These manuals are written as models which provide a framework to assist an individual library in formulating its own basic per- 
sonnel procedures. Designed for easy moditication these manuals treat all the generally accepted principles and procedures of sound personnel administration which a library should consider in preparing its own policy statement. Areas covered in the main sections are: objectives; organization and administration; relationship with community; classification of positions; salary schedules; appointments; development of the staff; performance evaluations; promotions, transfers, demotions, tenure; separation from service; working conditions; welfare and economic benefits; and staff relationships. Additional reference material appended include sample personnel forms, a suggested list of references, statements of Principles of Intellectual Freedom and Tenure for both Iibrarians and nonprofessional employees, the $\mathrm{Li}$ brary Bill of Rights, and the Resolution on Loyalty Programs. These revisions of the 1952 editions were prepared by the Personnel Publications Committee of LAD's Personnel Administration Section.

- Copies of the Publications List: 1968 are available at no charge from the Publications Office, University of Illinois Graduate School of Library Science, 435 Main Library, Urbana, Illinois 61801 .

- Scientific Serial Publications in the Joint University Libraries by Eleanor F. Morrissey is the title of a new computer-produced list of serial holdings in a major research library. The 138-page list records scientific serial holdings in JUL's science, biology, engineering, and medical (Vanderbilt University Medical Center library) libraries; some six thousand titles are listed. Copies of the list may be purchased for $\$ 1$ from the Data Processing Center, Joint University Libraries, Nashville, Tennessee 37203 .

- A Short Summary of the Papers and Proceedings of the Conference on the Bibliographic Control of Library Science Literature (A1bany, April 19-20, 1968) is now available for distribution. The papers and discussions considered the problem of improving library and indexing services for the field of library and information science. The conference, sponsored by ALA-LED and funded by a grant from the R. W. Wilson Foundation, was initiated and directed by the State University of New York Library at Albany. Single copies of the Short Summary and the previously released Summary of Recommendations (April 26, 1968) may be obtained by writing to: David Mitchell (COBCOL), University Library, B98, State University of New York at Albany, 1400 Washington Avenue, Albany, New York 12203.

- The Special Libraries Association's Documentation Division has published a Member- ship Directory. It is available to nonmembers for $\$ 3$ prepaid, from Mrs. Audrey N. Grosch, treasurer, SLA Documentation Division, 3314 Kyle Avenue North, Minneapolis, Minn. 55422.

- The National Fire Protection Association (NFPA) has just issued the Tentative Recommended Practice for Protection of Library Collections from Fire (NFPA No. 910-T). Intended as a guide for librarians, library trustees and others concerned with safekeeping of book collections, the new manual was adopted tentatively at the 1968 NFPA annual meeting and is subject to revision before being submitted for official NFPA adoption. The 36-page manual applying to library collections is intended to provide general recommendations and to point up problems which must be considered in protecting new and existing library buildings. There are sections on library construction, operation and maintenance, alterations and renovations, fire protection organization and training, and fire protection equipment. For information of a more technical nature, there are numerous references to other appropriate NFPA standards and codes. Copies (36 pages, $\$ 1.00$ ) are available from the $\mathrm{Na}$ tional Fire Protection Association, 60 Batterymarch Street, Boston, Mass. 02110.
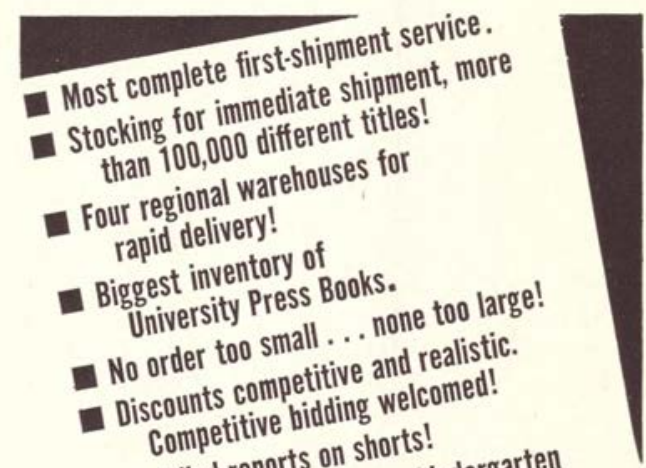
Discounts competitive and realistic. Competitive bidding welc Detailed reports on shorts? kindergarten More than 30,000 titles, kinderdard through high school-sting 60, per cataloging and processing shipment! book-ready for imm and / or our (Write for Elementary anoss)

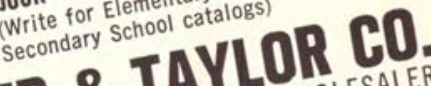

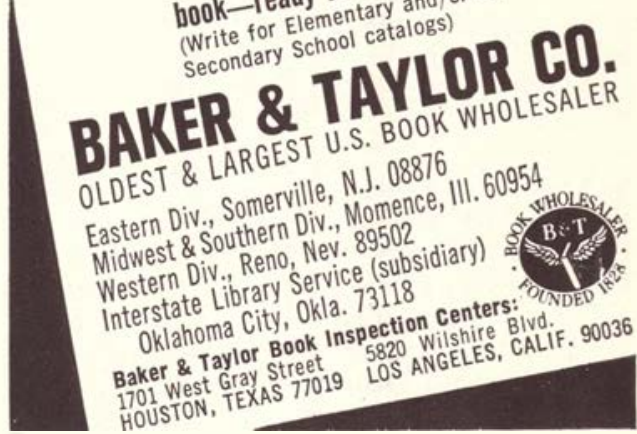

